\title{
Magnesium-limited growth of Aerobacter aerogenes in a chemostat
}

\author{
BY D. W. TEMPEST, J. R. HUNTER \\ Microbiological Research Establishment, Porton Down, Wiltshire \\ AND J. SYKES \\ Biochemistry Department, University of Sheffield
}

(Received 17 February 1965)

\begin{abstract}
SUMMARY
The influence of $\mathrm{Mg}^{2+}$-limitation, compared with carbon-limitation, on bacterial concentration, and on protein, carbohydrate, RNA and DNA contents of Aerobacter aerogenes cultures (grown in the chemostat at several dilution rates) was determined. In both types of culture the bacterial protein, carbohydrate and DNA contents varied slightly, and the RNA content grossly, with changes in dilution rate. Bacterial yield varied with growth rate, and to a marked degree in the $\mathbf{M g}^{2+}$-limited culture; this resulted from $\mathrm{Mg}^{2+}$ control of $\mathbf{R N A}$ synthesis. A growth-rate independent stoichiometry between RNA and $\mathrm{Mg}^{2+}$ was observed; 4 moles of RNA nucleotide were synthesized per mole of $\mathrm{Mg}^{2+}$ present in the culture. The protein and RNA distributions between cellular components varied with growth rate. The ribosomal fractions increased with increasing growth rate, as did the RNA: protein ratios in these fractions, in both cultures. $\mathrm{Mg}^{2+}$-limited bacteria contained little polysaccharide; washed suspensions of such organisms synthesized polysaccharide from glycerol at a low rate as compared with C-limited bacteria. Added $\mathrm{Mg}^{2+}$ stimulated polysaccharide synthesis by $\mathrm{Mg}^{2+}$-limite $\mathrm{d}$ bacteria but not by $\mathrm{C}$-limited bacteria. Washed suspensions of bacteria were induced to synthesize $\beta$-galactosidase. With cultures grown at three different dilution rates, the rates of enzyme synthesis in C-limited bacteria were twice those found with $\mathrm{Mg}^{2+}$-limited bacteria, though both had equal ribosome contents.
\end{abstract}

\section{INTRODUCTION}

The chemostat provides unique environmental conditions in which the concentration of bacteria is controlled by the concentration of a single component of the medium (all other nutrients being present in excess of requirement) and the growth rate is controlled by the rate of supply of this component to the culture. The 'growthlimiting' substance may be any compound or element essential for the growth of the organism; when it is an element such as magnesium, the bacteria produced must contain at least the minimum concentration of this material necessary to maintain structural integrity, and the functional ability to grow at the imposed rate. To relate observations on macromolecular organization and metabolic activity specifically to $\mathrm{Mg}^{2+}$-subsaturation it is necessary to compare $\mathrm{Mg}^{2+}$-limited cultures with similar cultures grown in the presence of excess $\mathrm{Mg}^{2+}$. To maintain comparable conditions the growth rate must then be controlled by the concentration of some 
other medium component. We chose to limit growth in the control culture by the supply of carbon source (glycerol).

Magnesium is an essential component of micro-organisms (Webb, 1949). It is known to be an integral part of ribosome structure (Tissières \& Watson, 1958), to be an activator of many enzyme systems (Dixon \& Webb, 1958) and to influence bacterial permeability (Brock, 1962). Sykes \& Tempest (1965) studied the influence of $\mathrm{Mg}^{2+}$-limitation on the physiology of a fluorescent pseudomonad and reported differences in RNA concentration, ribosome composition and metabolic activity, as compared with citrate-limited growth of the same organism. The present paper reports differences found between $\mathrm{Mg}^{2+-}$ limited and $\mathrm{C}$ (glycerol)-limited cultures of Aerobacter aerogenes grown at several dilution rates; some of these findings are in agreement with, and others differ from, those reported for the above Pseudomonas cultures.

\section{METHODS}

Organism. Aerobacter aerogenes (NCTC 418) was maintained and subcultured monthly on tryptic meat digest agar slopes.

Growth conditions. Organisms were grown in stirred glass chemostats of $500 \mathrm{ml}$. working volume, similar in design to that described by Elsworth, Meakin, Pirt \& Capell (1956). Temperature was controlled at $37^{\circ}$, and the $\mathrm{pH}$ value of the culture automatically adjusted to $6.5 \pm 0 \cdot 1$ by a control system similar to that described by Callow \& Pirt (1956). Regulated medium flow was effected by a D.C.L. Micropump (Distillers Co. Ltd., Epsom, Surrey) and the culture volume maintained constant by an internally placed overflow tube. The culture vessels, designed by Drs Herbert \& Phipps (to be published), permitted vigorous agitation and aeration of the culture; foaming was suppressed by the metered addition of an antifoam (Polyglycol-P2000; Dow Chemical Co., Midland, Michigan, U.S.A.).

Large samples of culture were collected from the overflow into ice-cooled receivers; smaller samples (less than $20 \mathrm{ml}$.) were drained directly from the culture without significantly influencing the 'steady state'.

$\mathrm{Mg}^{2+-l i m i t e d ~ m e d i u m ~ c o n t a i n e d: ~ c i t r i c ~ a c i d, ~} 1.0 \times 10^{-3} \mathrm{M} ;\left(\mathrm{NH}_{4}\right)_{2} \mathrm{SO}_{4}, 5.0 \times 10^{-2} \mathrm{M}$; $\mathrm{Na}_{2} \mathrm{HPO}_{4}, 5.0 \times 10^{-3} \mathrm{M} ; \mathrm{KH}_{2} \mathrm{PO}_{4}, 4.5 \times 10^{-2} \mathrm{M} ; \mathrm{CaCl}_{2}$ and $\mathrm{FeCl}_{3}$, each $0.1 \times 10^{-3} \mathrm{M}$; $\mathrm{MgCl}_{2}, 2.5 \times 10^{-4} \mathrm{M}$; trace amounts of $\mathrm{Mn}^{2+}, \mathrm{Cu}^{2+}$ and $\mathrm{Na}_{2} \mathrm{MoO}_{4}$. Glycerol was added to final concentration $50 \mathrm{mg} . / \mathrm{ml}$. Medium was made in $20 \mathrm{l}$. volumes, with distilled water which had been passed through a mixed-bed ion-exchange resin. The final $\mathrm{pH}$ was $5 \cdot 2 \pm 0 \cdot 1$ and at this value precipitation of salts did not occur, either on autoclaving $\left(121^{\circ}, 30 \mathrm{~min}\right.$.) or on standing at room temperature for periods of up to 3 weeks.

C-limited medium was similar to that described above except that the $\mathrm{Mg}^{2+}$ concentration was increased to $1 \cdot 25 \times 10^{-3} \mathrm{M}$, and the glycerol concentration decreased to $10 \mathrm{mg} . / \mathrm{ml}$.

Bacterial size. Bacteria were suspended in normal saline containing $0.5 \%(\mathrm{v} / \mathrm{v})$ formalin and size determinations carried out microscopically, with a Dyson imagesplitting eye-piece, in the manner described by Powell \& Errington (1963).

Colony counts of viable bacteria. These were made by spreading $0 \cdot 2 \mathrm{ml}$. volumes of a suspension of organisms, containing 300-600 viable organisms/ml. (prepared by successive dilutions in saline), on the dried surface of each of five nutrient agar plates. Colonies were counted after incubation for $16-24 \mathrm{hr}$ at $37^{\circ}$. 
Viability. Measurements were made by the slide-culture technique described by Postgate, Crumpton \& Hunter (1961).

Analytical procedures. Quantities of bacteria were measured by weighing ovendried $\left(104^{\circ}, 7 \mathrm{hr}\right)$ washed pastes from $5.0 \mathrm{ml}$. volumes of culture. Protein was determined by the biuret reaction (after Stickland, 1951) on heat treated $\left(100^{\circ}\right.$, 5 min., $\mathrm{N}-\mathrm{NaOH}$ ) bacterial suspensions. Bovine serum albumin, fraction 5 (Armour Laboratories) was used as standard. Ribonucleic acid was determined by the orcinol reaction (Militzer, 1946) with yeast ribonucleic acid (Boehringer and Son) as standard. Deoxyribonucleic acid was estimated by the method of Burton (1956) with calf thymus deoxyribonucleic acid (The British Drug Houses Ltd.) as standard; polysaccharide by the method of Fales (1951) with glucose as standard.

Fractionation procedure. Cultures (1-2 1.) collected in ice-cooled receivers were centrifuged (10,000 rev./min., $20 \mathrm{~min}$.) in the $6 \times 250 \mathrm{ml}$. angle head (no. 69179) of a MSE High Speed 17 refrigerated centrifuge. Packed bacteria were rinsed with icecold buffer $(0.01 \mathrm{M}$-tris $+0.001 \mathrm{M}$-magnesium acetate; $\mathrm{pH} \mathrm{7.5)}$, resuspended in buffer and again sedimented at $14,000 \mathrm{rev} . / \mathrm{min}$. in the $6 \times 100 \mathrm{ml}$. angle rotor (no. 69180 ). Bacterial pastes were transferred to a Hughes press (Hughes, 1951), precooled to $-20^{\circ}$, and the organisms crushed, the crushed pastes diluted with buffer $(4 \mathrm{ml} / \mathrm{g}$. frozen extract) and homogenized. Microscopical examination of the homogenate showed that the proportion of intact bacteria remaining was less than $0.1 \%$ of the initial populations.

Homogenates were centrifuged $(25,000 \mathrm{rev} . / \mathrm{min} ., 45 \mathrm{~min}$.) in a no. 30 rotor of a Spinco model $\mathbf{L}$ ultracentrifuge. Clear supernatant fluids decanted from compact fibrous deposits were again centrifuged $(40,000 \mathrm{rev} . / \mathrm{min} ., 2 \mathrm{hr})$ in a no. 40 rotor of a Spinco model L ultracentrifuge. Supernatant fractions were carefully separated from the glassy pellets and the latter resuspended in cold buffer to a measured final volume. The fibrous deposit was labelled 'debris', the final supernatant fluid 'supernatant fluid' and the glassy pellet 'ribosome' fraction.

$\beta$-Galactosidase induction and assay. $\beta$-Galactosidase was induced in aerated washed suspensions of bacteria (adjusted to about equiv. $0.8 \mathrm{mg}$. dry wt. $/ \mathrm{ml}$. in $0.067 \mathrm{M}$-phosphate buffer ( $\mathrm{pH} 6.5$ ) at $34^{\circ}$, by addition of methyl $\beta$-D-thiogalactopyranoside (0.001 M final concentration). Samples, taken at 45 min. intervals, were washed free from inducer with buffer and treated with benzene $(0 \cdot 1 \mathrm{ml} / 4 \cdot \mathbf{4} \mathrm{ml}$. sample) followed by shaking for $5 \mathrm{~min}$. at room temperature. The enzyme was assayed by determining 0 -nitrophenol (in alkaline solution) released from $0.002 \mathrm{M}$ $o$-nitrophenylgalactoside after $15 \mathrm{~min}$. at $34^{\circ}$ in $0.067 \mathrm{M}$-phosphate buffer ( $\mathrm{pH} \mathrm{7 \cdot 2)}$.

$R N A$ and $D N A$ synthesis. Bacteria from each culture, grown at a dilution rate of $0.2 \mathrm{hr}^{-1}$, were washed by centrifugation from a $\mathrm{Mg}^{2+}$-deficient medium ( $\mathrm{pH} \mathrm{6.5}$; the medium used for growth of $\mathrm{Mg}^{2+}$-limited organisms but without added $\mathrm{Mg}^{2+}$ ). Washed organisms were suspended in this medium to a final concentration equiv. $2 \mathrm{mg}$. dry wt. organisms $/ \mathrm{ml}$. and incubated at $37^{\circ}$ on a reciprocating shaker. Samples $(5.0 \mathrm{ml}$.) were taken at $0.5 \mathrm{hr}$ intervals, washed by centrifugation from distilled water and resuspended in distilled water $(5.0 \mathrm{ml}$. final volume). Samples were extracted at $4^{\circ}$ with $0.25 \mathrm{~N}-\mathrm{HClO}_{4}$ for $0.5 \mathrm{hr}$; organisms were sedimented in the centrifuge and resuspended to a known volume in $0.5 \mathrm{~N}-\mathrm{HClO}_{4}$. After incubating the suspension at $70^{\circ}$ for $0.5 \mathrm{hr}$, organisms were removed by centrifugation and RNA and DNA analyses carried out on the supernatant solution. 
Polysaccharide synthesis. Bacteria from each culture, grown at a dilution rate of $0.2 \mathrm{hr}^{-1}$ were washed by centrifugation from $0.067 \mathrm{~m}-$ phosphate $(\mathrm{pH} \mathrm{6.5})$ and suspended in this buffer to a final concentration of equiv. about $2 \mathrm{mg}$. dry wt./ml. Glycerol was added to final concentration $5 \mathrm{mg}$. $/ \mathrm{ml}$. and, where necessary, $\mathrm{Mg}^{2+}$ to a final concentration of $5 \mathrm{~mm}$. Suspensions were incubated at $37^{\circ}$ on a reciprocating shaker, and samples $(4.0 \mathrm{ml}$.) taken at intervals of $0.5 \mathrm{hr}$. Samples were washed by suspension and centrifugation from distilled water, resuspended in distilled water to final volume $10 \mathrm{ml}$. and $0.5-1 \cdot 0 \mathrm{ml}$. samples taken for analysis.

\section{RESULTS}

The influence of $\mathrm{Mg}^{2+}$ concentration on bacterial concentration in $\mathbf{M g}^{2+}$-limited cultures

In the chemostat the 'steady state' bacterial concentration is a function of limiting nutrient concentration, $K_{s}$ and dilution rate $\mathrm{D}$ (Herbert, Elsworth \& Telling, 1956). At a fixed dilution rate bacterial yield (g. dry wt. organism formed/g. limiting nutrient consumed) is constant. Figure 1 shows the 'steady state' concentration of organisms determined for three $\mathrm{Mg}^{2+}$ input concentrations. The fact that there was a linear relationship between these points showed that the cultures were limited in their growth solely by the availability of $\mathrm{Mg}^{2+}$; that the line extrapolated to zero concentration indicated that the culture had an absolute $\mathbf{M g}^{2+}$ requirement for growth in this simple salts medium (see Webb, 1949).

Table 1. Variation in bacterial size and growth yield with dilution rate for Aerobacter aerogenes

\begin{tabular}{|c|c|c|c|c|}
\hline \multirow[b]{2}{*}{ D } & \multicolumn{2}{|c|}{$\mathbf{M g}^{2+-}$-limited* } & \multicolumn{2}{|c|}{ C-limited } \\
\hline & Cell size & & Cell size & \\
\hline$\left(h r^{-1}\right)$ & $(\mu)$ & Yield $\dagger$ & $(\mu)$ & Yield $\neq$ \\
\hline $0 \cdot 09$ & - & - & - & $0.373 \S$ \\
\hline $0 \cdot 10$ & - & 832 & 一 & 0.432 \\
\hline 0.20 & $2.06 \times 0.90$ & 588 & $1.55 \times 0.70$ & $0 \cdot 452$ \\
\hline $0 \cdot 20$ & - & 673 & - & 0.512 \\
\hline $0 \cdot 39$ & - & - & - & $0 \cdot 498$ \\
\hline $0 \cdot 40$ & $2.14 \times 0.90$ & - & $1.64 \times 0.73$ & - \\
\hline $0 \cdot 41$ & - & 460 & - & 0.504 \\
\hline $0 \cdot 43$ & - & 432 & - & - \\
\hline 0.60 & - & 378 & - & 0.510 \\
\hline 0.82 & $3.26 \times 1 \cdot 11$ & 347 & $2.53 \times 0.91$ & 0.540 \\
\hline
\end{tabular}

* Viability did not vary beyond the range $95-100 \%$, at any dilution rate, in either type of culture.

$\dagger$ g. bacteria/g. $\mathrm{Mg}^{2+}$. $\ddagger$ g. bacteria/g. glycerol.

$\S$ Figures not corrected for dilution by $\mathrm{pH}$ titrant (3-6\% medium input rate).

Influence of dilution rate on the yield constant and average cell size

Herbert (1958) reported that with C-limited chemostat cultures of Aerobacter aerogenes both the 'yield' and mean size were functions of the dilution rate. Table 1 shows comparable figures for $\mathrm{Mg}^{2+}$-limited and $\mathrm{C}$-limited cultures of this organism. In both types of culture organism size varied with changes in dilution rate but, at corresponding growth rates, $\mathrm{Mg}^{2+-}$-limited bacteria were, on average, the larger. In 
agreement with Webb (1949) we observed few aberrant forms in these 'defined' environments. The yield varied with dilution rate in both cultures but not in a like manner. With the C-limited culture a decrease in yield at low dilution rate occurred; this was attributed by Herbert (1958) to endogenous metabolism. The reverse change in yield with dilution rate found with the $\mathrm{Mg}^{2+}$-limited culture was similar to that reported by Herbert (1961) to occur with N-limited cultures of Torula utilis, and to be due to intracellular deposition of polysaccharide material. No excess polysaccharide was, however, detected in these $\mathrm{Mg}^{2+}$-limited $A$. aerogenes bacteria (see Table 2). Postgate \& Hunter (1962) reported a variation in yield with dilution rate in $\mathrm{Mg}^{2+}$-limited cultures of a variant of this organism; their yields were in good agreement with the figures quoted in Table 1.

Table 2. Gross composition of Aerobacter aerogenes grown at different dilution rates

Values are expressed as g. component/100 g. lyophilized bacteria.

\begin{tabular}{|c|c|c|c|c|c|}
\hline $\begin{array}{c}\text { D } \\
(\text { vol./hr) }\end{array}$ & Protein & $\begin{array}{c}\text { Acid sol. } \\
\text { material } \\
\text { (as RNA) }\end{array}$ & RNA & DNA & $\begin{array}{l}\text { Carbo- } \\
\text { hydrate }\end{array}$ \\
\hline \multicolumn{6}{|c|}{$\mathrm{Mg}^{2+}$-limited } \\
\hline $0 \cdot 1$ & $75 \cdot 0$ & $0 \cdot 66$ & $8 \cdot 75$ & $3 \cdot 59$ & $2 \cdot 17$ \\
\hline $0 \cdot 1$ & $73 \cdot 6$ & $0 \cdot 72$ & $8 \cdot 00$ & $3 \cdot 43$ & $2 \cdot 48$ \\
\hline $0 \cdot 2$ & $79 \cdot 0$ & $0 \cdot 64$ & $11 \cdot 50$ & $3 \cdot 83$ & $2 \cdot 59$ \\
\hline $0 \cdot 2$ & $72 \cdot 3$ & $0 \cdot 98$ & $10 \cdot 55$ & $3 \cdot 49$ & $2 \cdot 19$ \\
\hline $0 \cdot 4$ & $74 \cdot 7$ & 0.94 & $15 \cdot 00$ & $3 \cdot 15$ & - \\
\hline $0 \cdot 4$ & $70 \cdot 0$ & $1 \cdot 12$ & $15 \cdot 15$ & $3 \cdot 29$ & $\mathbf{2} \cdot \mathbf{8 4}$ \\
\hline $0 \cdot 8$ & $69 \cdot 0$ & $1 \cdot 70$ & $16 \cdot 40$ & $2 \cdot 64$ & - \\
\hline $0 \cdot 8^{*}$ & $66 \cdot 3$ & 0.96 & $13 \cdot 10^{*}$ & $2 \cdot 69$ & $4 \cdot 29$ \\
\hline \multicolumn{6}{|c|}{ C-limited } \\
\hline $0 \cdot 1$ & $72 \cdot 2$ & $0 \cdot 90$ & $9 \cdot 50$ & $4 \cdot 20$ & $3 \cdot 79$ \\
\hline $0 \cdot 1$ & $74 \cdot 0$ & $0 \cdot 84$ & $9 \cdot 25$ & $4 \cdot 23$ & $3 \cdot 36$ \\
\hline $0 \cdot 2$ & $71 \cdot 0$ & $0 \cdot 90$ & $10 \cdot 35$ & $4 \cdot 27$ & $2 \cdot 88$ \\
\hline $0 \cdot 2$ & $73 \cdot 5$ & 0.80 & $10 \cdot 75$ & $4 \cdot 61$ & $2 \cdot 77$ \\
\hline $0 \cdot 4$ & $76 \cdot 0$ & $0 \cdot 88$ & 13.95 & $4 \cdot 27$ & $3 \cdot 29$ \\
\hline $0 \cdot 4$ & $73 \cdot 6$ & $1 \cdot 16$ & $14 \cdot 30$ & $4 \cdot 31$ & - \\
\hline $0 \cdot 8$ & $69 \cdot 8$ & 0.96 & $18 \cdot 60$ & $3 \cdot 12$ & $3 \cdot 54$ \\
\hline $0 \cdot 8$ & $67 \cdot 3$ & 0.96 & $18 \cdot 00$ & $2 \cdot 97$ & $3 \cdot 30$ \\
\hline
\end{tabular}

* Change in cell composition following temporary $\mathrm{pH}$ control failure.

Variations in macromolecular composition with changes in growth rate

The gross macromolecular composition of the bacteria, grown at four dilution rates, in each type of culture is detailed in Table 2. At similar dilution rates minor differences were apparent between the two cultures. Over much of the range of dilution rates $\mathrm{Mg}^{2+}$-limited bacteria contained, on a dry-weight basis, less polysaccharide and DNA than C-limited organisms, but considering the differences in average bacterial size (Table $\mathrm{I}$ ), the contents per bacterium were similar.

The RNA content of bacteria from each culture was a function of growth rate. This has also been found with sulphur-, phosphorus-, and nitrogen-limited cultures of this organism (Dr D. Herbert, personal communication). Although only small differences were apparent between cellular RNA contents at corresponding dilution rates, the influence of dilution rate on culture-RNA content was strikingly different. 
Fig. 2 shows that whereas in C-limited environments the culture-RNA concentration was a function of dilution rate, it was independent of this parameter when the $\mathrm{Mg}^{2+}$ concentration limited growth. In this latter case the increase in cellular-RNA in faster growing cultures was offset by a decrease in the bacterial concentration (Table 3) such that the culture-RNA concentration remained constant over the whole range of dilution rates examined. This finding suggests that $\mathrm{Mg}^{2+}$ regulated RNA synthesis.

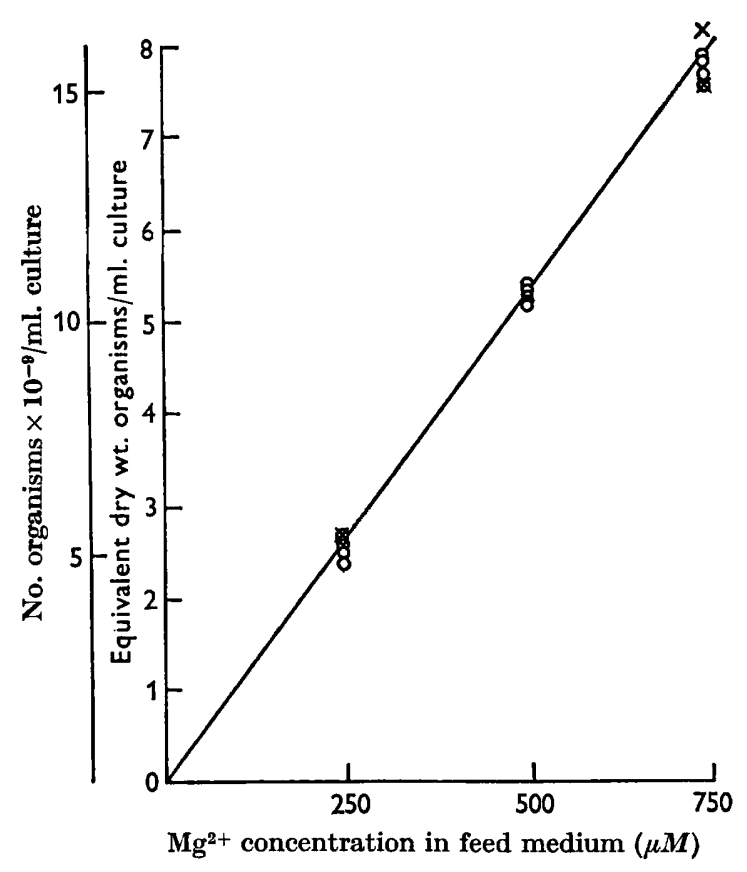

Fig. 1

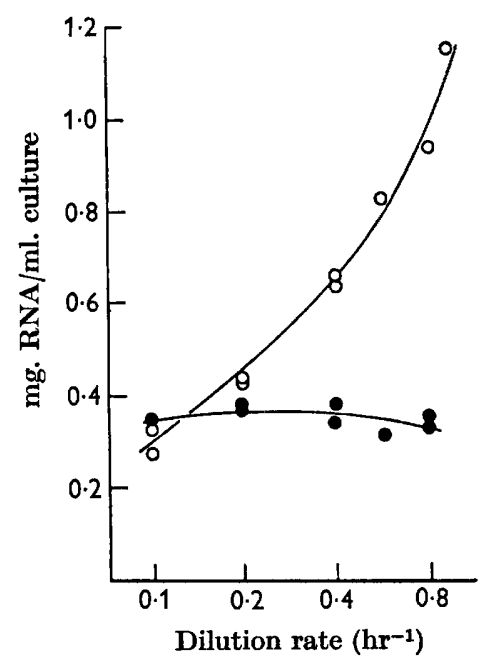

Fig. 2

Fig. 1. Bacterial concentration versus $\mathrm{Mg}^{2+}$ concentration in $\mathrm{Mg}^{2+-}$ limited cultures of Aerobacter aerogenes growing in the chemostat at a dilution rate of $0 \cdot 4 \mathrm{hr}^{-1}$. 0 , Equivalent dry wt. organism $/ \mathrm{ml}$. culture; $x$, number of viable bacteria $/ \mathrm{ml}$. culture.

Fig. 2. Variation in culture-RNA concentration with dilution rate in $\mathrm{Mg}^{2+}$-limited, and in C-limited, cultures of Aerobacter aerogenes., RNA concentration (mg. $/ \mathrm{ml}$. culture) in the $\mathrm{Mg}^{2+}$-limited culture; $\mathrm{O}$, RNA concentration (mg. $/ \mathrm{ml}$. culture) in the C-limited culture.

With an input $\mathrm{Mg}^{2+}$ concentration of $6 \mu \mathrm{g} . / \mathrm{ml}$. in the $\mathrm{Mg}^{2+-}$ limited culture, the culture-RNA concentration was $350 \pm 40 \mu \mathrm{g}$. $/ \mathrm{ml}$. over a range of dilution rates from 0.10 to $0.82 \mathrm{hr}^{-1}$. Assuming nearly complete $\mathrm{Mg}^{2+}$ utilization, the molar RNA nucleotide: $\mathrm{Mg}^{2+}$ ratio was approximately 4 . As some intracellular $\mathrm{Mg}^{2+}$ must have been serving a metabolic role, and was therefore not available for ribonucleoprotein stabilization, the ribosomal RNA nucleotide: $\mathbf{M g}^{2+}$ ratio must approach $\mathbf{5}$ which, according to Edelman, Ts'o \& Vinograd (1960), is the limit for stability in vitro of 80S (rabbit reticulocyte) ribosomes. The figures for DNA content (Tables 2, 3) indicate that a constant $\mathrm{DNA}: \mathrm{Mg}^{2+}$ ratio did not hold in $\mathrm{Mg}^{2+-}$ limited bacteria. 
$R N A$ and $D N A$ synthesis by organisms incubated in a $\mathrm{Mg}^{2+}$-deficient medium

The stoichiometry between culture $\mathrm{Mg}^{2+}$ and RNA contents suggests that $\mathrm{Mg}^{2+}$ controls RNA synthesis. In partial support of this was the observation (Tables 2, 3) that when a shift in the 'steady state' concentration of the bacteria occurred (following a temporary failure in the $\mathrm{pH}$ control system) the culture-RNA content did not vary; the cellular-RNA content changed from $16 \cdot 4$ to $13 \cdot 1 \%$ of the dry weight.

Table 3. Variation in bacterial concentration, $R N A$ and $D N A$ concentration with changes in dilution rate for Aerobacter aerogenes

\begin{tabular}{|c|c|c|c|c|}
\hline \multirow{3}{*}{$\underset{(\text { vol. } / \mathrm{hr})}{\mathrm{D}}$} & \multirow{3}{*}{ Dry wt. } & \multicolumn{2}{|c|}{ RNA } & \multirow{3}{*}{ DNA } \\
\hline & & $\begin{array}{l}\text { Cold Acid } \\
\text { Sol. }\end{array}$ & $\begin{array}{l}\text { Cold Acid } \\
\text { Insol. }\end{array}$ & \\
\hline & & \multicolumn{2}{|c|}{ mg./ml. culture } & \\
\hline \multicolumn{5}{|c|}{$\mathbf{M g}^{2+}-$ limited } \\
\hline $0 \cdot 10$ & 4.99 & 0.038 & $0 \cdot 334$ & - \\
\hline 0.20 & 3.53 & 0.050 & $0 \cdot 388$ & 0.092 \\
\hline $0 \cdot 20$ & 4.04 & 0.030 & $0 \cdot 374$ & $0 \cdot 103$ \\
\hline 0.41 & $2 \cdot 76$ & 0.035 & $0 \cdot 346$ & 0.080 \\
\hline 0.48 & $2 \cdot 59$ & 0.035 & 0.384 & - \\
\hline 0.60 & $2 \cdot 27$ & $0 \cdot 039$ & 0.314 & - \\
\hline 0.82 & $2 \cdot 08$ & 0.036 & $0 \cdot 340$ & 0.055 \\
\hline $0 \cdot 79$ & $2 \cdot 56^{*}$ & 0.035 & 0.362 & - \\
\hline \multicolumn{5}{|c|}{ C-limited } \\
\hline 0.09 & 3.73 & 0.024 & $0 \cdot 266$ & - \\
\hline $0 \cdot 10$ & $4 \cdot 32$ & 0.043 & 0.314 & - \\
\hline $0 \cdot 20$ & 4.52 & $0 \cdot 048$ & $0 \cdot 430$ & $0 \cdot 151$ \\
\hline $0 \cdot 20$ & $5 \cdot 12$ & 0.036 & $0 \cdot 436$ & $0 \cdot 158$ \\
\hline $0 \cdot 39$ & $4 \cdot 98$ & 0.060 & 0.616 & $0 \cdot 130$ \\
\hline $0 \cdot 40$ & $5 \cdot 04$ & 0.062 & $0 \cdot 636$ & - \\
\hline 0.60 & $5 \cdot 10$ & 0.056 & 0.826 & - \\
\hline 0.81 & $\mathbf{5} \cdot \mathbf{4 4}$ & 0.066 & 0.940 & - \\
\hline $0 \cdot 82$ & $5 \cdot 40$ & 0.077 & $1 \cdot 154$ & - \\
\hline
\end{tabular}

* Unexplainable shift in steady state bacterial concentration following trouble with pH control. See Table 2 and text.

A further indication that RNA synthesis was controlled by the availability of $\mathbf{M g}^{2+}$ was obtained from observations of RNA and DNA synthesis by washed suspensions of $\mathrm{Mg}^{2+}$-limited organisms and of C-limited organisms, incubated in a $\mathrm{Mg}^{2+}$. deficient medium (Fig. 3). C-limited bacteria, which were found on analysis to contain twice the $\mathrm{Mg}^{2+}$ concentration of $\mathrm{Mg}^{2+}$-limited organisms grown at the same dilution rate, synthesized considerably more $\mathbf{R N A}$ than did $\mathbf{M g}^{2+}$-limited organisms. Some RNA was, however, synthesized by the latter; this may have reflected $\mathrm{Mg}^{2+}$ contamination of the medium or utilization of residual unbound $\mathrm{Mg}^{2+}$ in the organisms. In contrast to this finding little difference was found between the rates of DNA synthesis in the two cultures (Fig. 3). 


\section{Variations in cell protein and $R N A$ distribution with changes in dilution rate}

Protein and RNA contents of $\mathrm{Mg}^{2+}$-limited and C-limited bacteria, grown at the same dilution rates, were similar. In view, however, of the strong evidence that $\mathrm{Mg}^{2+}$ stabilizes ribosomal structures in vitro (Edelman et al. 1960; Ohtaka \& Uchida, 1963) and in vivo (McCarthy, 1962), it is pertinent to inquire whether the RNA is distributed in a like manner in bacteria from the two kinds of cultures examined here. Detailed in Table 4 are the distribution patterns for protein and RNA in the two types of culture, grown at four different dilution rates (D). At corresponding values of $\mathrm{D}$ the RNA distribution patterns were very similar. Differences in protein distribution were apparent, particularly with respect to the 'debris' fraction. These, and the variation in 'debris' protein with dilution rate, must be viewed against the fact that bacterial size (and hence surface area: volume ratio) is a function of growth-limiting condition and growth rate.

Table 4. Distribution of protein and $R N A$ between fractions derived from Hughes press disintegrates of Aerobacter aerogenes

Protein*

mg./ml. homog. protein

\begin{tabular}{|c|c|c|c|c|c|c|c|c|}
\hline$\underset{\text { (vol./hr) }}{\text { D }}$ & $\begin{array}{l}\text { Homo- } \\
\text { genate }\end{array}$ & Debris & $\begin{array}{l}\text { Super- } \\
\text { natant } \\
\text { fluid }\end{array}$ & Ribosome & $\begin{array}{l}\text { Homo- } \\
\text { genate }\end{array}$ & Debris & $\begin{array}{c}\text { Super- } \\
\text { natant } \\
\text { fluid }\end{array}$ & Ribosome \\
\hline \multicolumn{9}{|c|}{$\mathrm{Mg}^{2+-}$-limited } \\
\hline $0 \cdot 1$ & $1 \cdot 0$ & $0 \cdot 41$ & $0 \cdot 46$ & $0 \cdot 13$ & $0 \cdot 12$ & $0 \cdot 04$ & 0.03 & 0.05 \\
\hline 0.2 & $1 \cdot 0$ & $0 \cdot 40$ & 0.47 & $0 \cdot 13$ & $0 \cdot 15$ & 0.06 & 0.04 & 0.05 \\
\hline $0 \cdot 4$ & $1 \cdot 0$ & $0 \cdot 35$ & 0.50 & $0 \cdot 15$ & $0 \cdot 19$ & 0.05 & 0.06 & 0.08 \\
\hline 0.8 & $1 \cdot 0$ & $0 \cdot 33$ & $0 \cdot 49$ & $0 \cdot 18$ & 0.25 & 0.06 & $0 \cdot 07$ & $0 \cdot 12$ \\
\hline \multicolumn{9}{|c|}{ C-limited } \\
\hline $0 \cdot 1$ & 1.0 & 0.38 & $0 \cdot 48$ & $0 \cdot 14$ & $0 \cdot 13$ & 0.04 & 0.04 & 0.05 \\
\hline 0.2 & $1 \cdot 0$ & 0.43 & $0 \cdot 42$ & $0 \cdot 14$ & $0 \cdot 16$ & 0.06 & $0 \cdot 04$ & 0.06 \\
\hline 0.4 & $1 \cdot 0$ & 0.40 & 0.46 & $0 \cdot 14$ & $0 \cdot 18$ & 0.06 & 0.05 & 0.07 \\
\hline $0 \cdot 8$ & $1 \cdot 0$ & $0 \cdot 38$ & 0.44 & $0 \cdot 18$ & $0 \cdot 28$ & 0.08 & 0.07 & $0 \cdot 13$ \\
\hline
\end{tabular}

* The figures quoted in this table are mean values from two cultures harvested and processed on separate days.

In agreement with the observations of Ecker \& Schaechter (1963) we found the ribosome concentration to be a function of growth rate. It is evident from Table 4, however, that the relative RNA and protein contributions to the ribosomal fractions varied with dilution rate. At a dilution rate of $0.2 \mathrm{hr}^{-1}$ the RNA:protein ratios were $\mathbf{0 . 4 3}$ and $\mathbf{0 . 3 8}$, respectively, for preparations from $\mathrm{C}$-limited and $\mathrm{Mg}$-limited bacteria, increasing to values of 0.72 and 0.67 , respectively, at a dilution rate of $0 \cdot 8 \mathrm{hr}^{-1}$.

Purification of the ribosomal fractions from C-limited and $\mathrm{Mg}^{2+-}$ limited bacteria, grown at a dilution rate of $0.2 \mathrm{hr}^{-1}$, by sedimentation for $2 \mathrm{hr}$ (twice) from $0.01 \mathrm{M}$ tris $+0.001 \mathrm{M}$-magnesium acetate $(\mathrm{pH} \mathrm{7.5})$ at $35,000 \mathrm{rev} . / \mathrm{min}$. in the SW. 39 rotor of a Spinco preparative ultracentrifuge, yielded preparations which on analysis were found to contain RNA and protein in the ratios of 0.80 and 0.71 , respectively. During purification $49.5 \%$ of the initial ribosomal RNA and $74.5 \%$ of the initial ribosomal protein was not recovered in the C-limited preparation; corresponding 
figures for a $\mathrm{Mg}^{2+-}$ limited preparation were $39.5 \% \mathrm{RNA}$ and $68.0 \%$ protein. Part of these losses can be attributed to removal of occluded material, but breakdown of ribosomal structures was indicated by the appearance of insoluble material on resuspension of the ribosomal pellets.

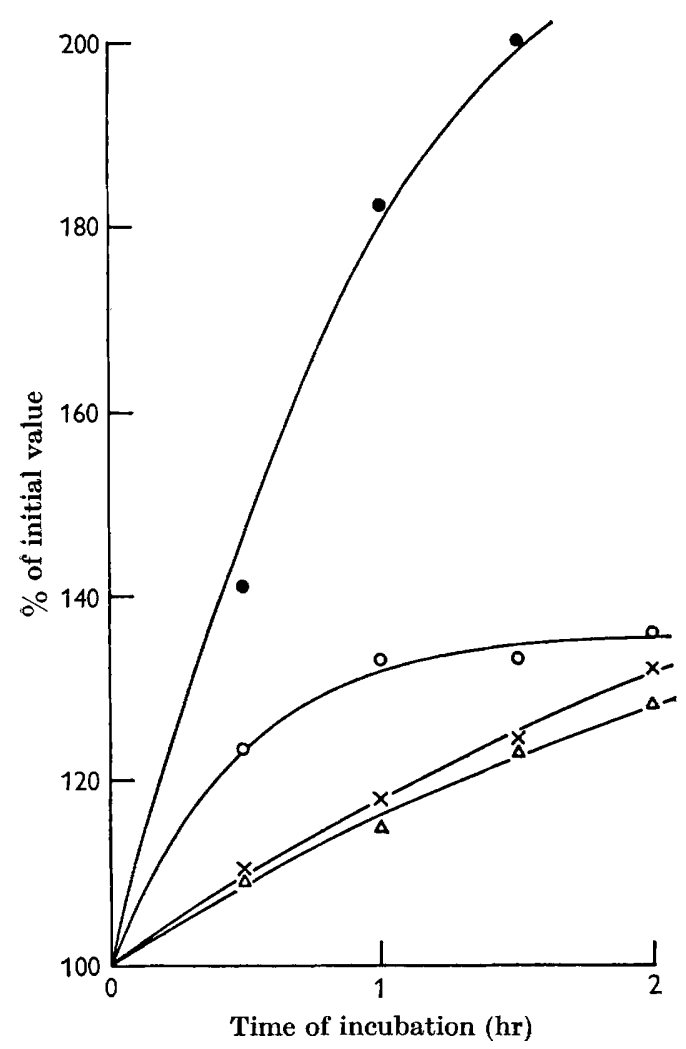

Fig. 3

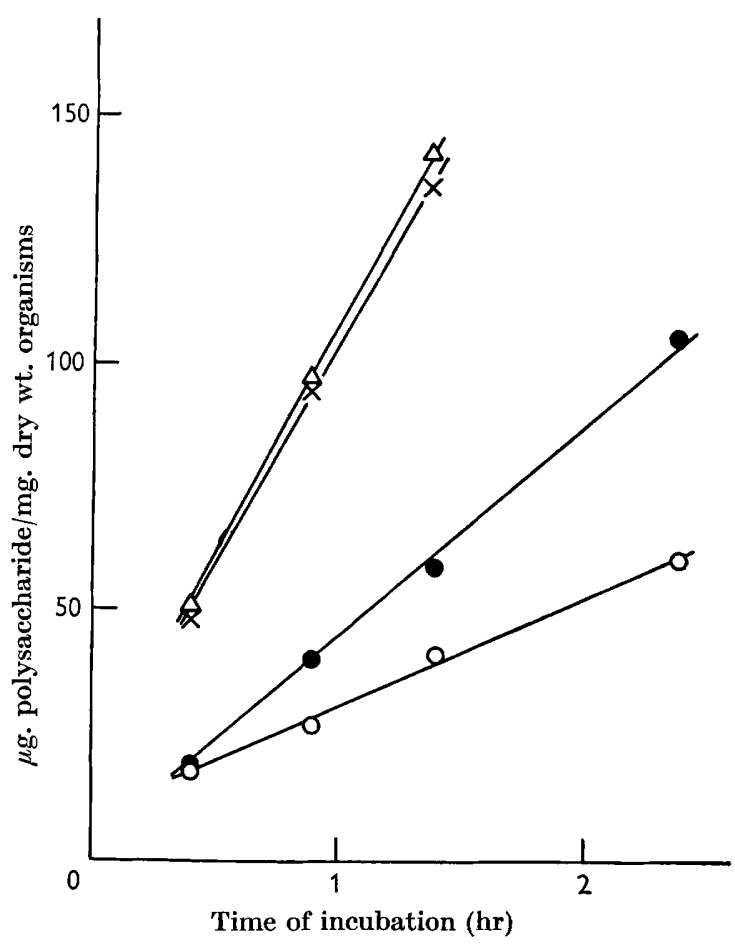

Fig. 4

Fig. 3. RNA and DNA synthesis by $\mathrm{Mg}^{2+-}$-limited and by $\mathrm{C}$-limited Aerobacter aerogenes organisms incubated in a $\mathrm{Mg}^{2+}$-deficient medium at $37^{\circ}$ and $\mathrm{pH} 6 \cdot 5$. $O$, RNA synthesis and $\times$, DNA synthesis by $\mathrm{Mg}^{2+}$-limited organisms; 0 , RNA synthesis and $\triangle$, DNA synthesis by C-limited organisms.

Fig. 4. Polysaccharide synthesis by washed suspensions of Aerobacter aerogenes. Organisms suspended in $0.067 \mathrm{~m}$-phosphate $(\mathrm{pH} 6.5)$, containing $0.5 \%(\mathrm{w} / \mathrm{v})$ glycerol. $\mathrm{Mg}^{2+}$-limited organisms were incubated $(O)$ in the absence of, and $(O)$ in the presence of $5 \mathrm{~mm}-\mathrm{Mg}^{2+}$. C-limited organisms were incubated $(x)$ in the absence of, and $(\Delta)$ in the presence of $5 \mathrm{~mm}-\mathrm{Mg}^{2+}$.

\section{Polysaccharide synthesis in $\mathbf{M g}^{2+}$-limited bacteria}

Nitrogen-limited or sulphur-limited bacteria grown at low dilution rates in a glycerol salts medium contained quantities of polysaccharide material in excess of that found in bacteria from a carbon-limited culture (Dr D. Herbert, personal communication). This suggests that, at these dilution rates, polysaccharide synthesis resulted solely from excess glycerol in the environment; the absence of a repressor substance does not seem to have been an influencing factor.

In Table $\mathbf{2}$ it is apparent that $\mathrm{Mg}^{2+}$-limited bacteria grown at low dilution rates 
contained less polysaccharide than C-limited bacteria, indicating an impaired ability to synthesize this material. Observations on the rates of polysaccharide synthesis by washed suspensions of C-limited and $\mathrm{Mg}^{2+}$-limited bacteria (Fig. 4) showed that without added $\mathrm{Mg}^{2+}$ the former synthesized polysaccharide from glycerol at about four times the rate of the latter $(87$ versus $18 \mu \mathrm{g} . / \mathrm{mg}$. bacterial dry wt. $/ \mathrm{hr}$, at $\left.37^{\circ}\right)$. Addition of $\mathrm{Mg}^{2+}$ to the suspending medium had little effect with the C-limited bacteria, but markedly stimulated synthesis in bacteria from the $\mathrm{Mg}^{2+}$-limited culture. The rate of polysaccharide synthesis was still, however, twice as high in bacteria from the C-limited culture $(92$ versus $44 \mu \mathrm{g} . / \mathrm{mg}$. bacterial dry wt. $/ \mathrm{hr}$ at $\left.37^{\circ}\right)$. It would seem, therefore, that the low polysaccharide content of $\mathrm{Mg}^{2+}$-limited bacteria resulted from both decreased enzyme biosynthesis and a lack of excess free $\mathbf{M g}^{2+}$.

Table 5. Initial rates of synthesis by Aerobacter aerogenes of $\beta$-galactosidase after exposure to methyl $\beta$-D-thiogalactopyranoside and incubation at $34^{\circ}$

\begin{tabular}{llll}
$\begin{array}{l}\text { Limiting } \\
\text { component }\end{array}$ & $\overbrace{0.1}$ & \multicolumn{3}{c}{$\begin{array}{c}0.4 \\
0.8\end{array}$} \\
& \multicolumn{3}{c}{ Ratution of synthesis* } \\
Carbon & $\overbrace{0.12}$ & 0.21 & 0.21 \\
$M^{2+}$ & 0.06 & 0.12 & 0.09
\end{tabular}

* Rates expressed as change in extinction $E_{420} / \mathrm{mg}$. dry wt. bacteria/hr.

\section{Rates of $\beta$-galactosidase synthesis}

$\mathrm{Mg}^{2+}$-limited bacteria contained sufficient $\mathrm{Mg}^{2+}$ to maintain the functional ability necessary for growth at the imposed rate. From Table 2 it follows that, at similar dilution rates, the rates of protein synthesis in $\mathbf{C}$-limited and $\mathbf{M g}^{\mathbf{2}}$-limited cultures were identical. Protein synthesis in C-limited bacteria must be limited by the availability of monomers, whereas this may well not be true for $\mathbf{M g}^{\mathbf{2}+\text {-limited }}$ bacteria where nitrogen-, carbon-, and energy-sources are readily available. It seems probable, therefore, that, though in the growing cultures the rates of protein synthesis were similar, their biosynthetic potentials differed.

Determination of rates of induced enzyme synthesis may be used as a measure of protein synthesizing ability. Table 5 lists the initial rates of $\beta$-galactosidase synthesis in bacteria from $\mathrm{C}$-limited and from $\mathrm{Mg}^{2+}$-limited cultures following exposure to the gratuitous inducer methyl $\beta$-D-thiogalactopyranoside. It is apparent that $\beta$-galactosidase synthesis in $\mathrm{C}$-limited bacteria was more rapid than in $\mathrm{Mg}^{2+}$ limited bacteria grown at the same rate. The lower biosynthetic rate observed in the latter did not appear to result from lack of free $\mathrm{Mg}^{2+}$; addition of $\mathrm{MgCl}_{2}(1 \mathrm{~mm})$ to the induction medium did not effect a significant increase in the rate of enzyme synthesis.

\section{DISCUSSION}

Whereas $\mathrm{Mg}^{2+-}$ limited Pseudomonas fluorescens organisms differed from C-limited $\boldsymbol{P}$. fluorescens in their total RNA content and ribosome composition (Sykes \& Tempest, 1965), no consistent difference in RNA content was observed between $\mathrm{Mg}^{2+-}$ limited and C-limited Aerobacter aerogenes cultures. The difference in the RNA: protein ratios found between purified ribosome preparations from the $\mathrm{Mg}^{2+}$ 
limited and C-limited $A$. aerogenes (grown at a dilution rate $0.2 \mathrm{hr}^{-1}$ ) was much smaller than that reported for $\boldsymbol{P}$. fluorescens. In agreement with the observations of Sykes \& Tempest (1965) we find that the RNA: protein ratios of the crude ribosome fractions of $A$. aerogenes increased with increasing growth rate. This change in composition may reflect a change in the basic ribosome structure, but might result from a variation in the degree of messenger-RNA and/or nascent protein associated with the ribosomes. Furthermore, a varying susceptibility to ribonuclease attack, or variation in the activity of this enzyme with growth rate (see Brody, 1957) might be contributing factors. Although the available evidence does not permit a decision between these possibilities it is clear from the present investigation, and the observations of others (Wade \& Robinson, 1963; Lucas, Schuurs \& Simpson, 1964) that both growth conditions and genetic differences can influence ribosome content, composition and activity.

The finding of a linear relationship between bacterial dry weight and input $\mathrm{Mg}^{2+}$ concentration which extrapolates to zero (Fig. 1) clearly shows that magnesium is essential for growth of Aerobacter aerogenes in a simple salts environment (see Webb, 1949) and suggests quantitative uptake of $\mathrm{Mg}^{2+}$ from the environment. The RNA, DNA and protein contents of $\mathrm{Mg}^{2+}$-limited $A$. aerogenes did not appear to differ significantly from $\mathrm{C}$-limited organisms grown at corresponding rates (Table 2) nor, taking into account the increased polysaccharide contents, from similar cultures grown in $\mathrm{NH}_{4}{ }^{+}$-limiting or $\mathrm{SO}_{4}{ }^{2-}$-limiting environments (Dr D. Herbert, personal communication). This is particularly evident with the bacterial RNA contents, which vary markedly with growth rate. In $\mathrm{Mg}^{2+}$-limited $A$. aerogenes the bacterial yield (g. dry wt. bacteria formed/g. $\mathrm{Mg}^{2+}$ ) is also a function of growth rate but the culture-RNA content (g. RNA/ml. culture) is independent of this parameter. Clearly this stoichiometry between culture-RNA and $\mathbf{M g}^{2+}$ suggests $\mathbf{M g}^{2+}$ control of RNA synthesis. This hypothesis is supported by the finding (Fig. 3) that washed suspensions of $\mathrm{Mg}^{2+}$-limited $A$. aerogenes are less able to synthesize RNA than similar suspensions of $\mathrm{C}$-limited organisms. It is not obvious how $\mathrm{Mg}^{2+}$ can control RNA synthesis but it is apparent from Table 4 that both ribosomal-RNA and soluble-RNA were equally subject to this control in our experiments.

Kennell \& Magasanik (1962) showed that Aerobacter aerogenes organisms depleted in ribosomes by incubation in a $\mathrm{Mg}^{2+}$-deficient medium, synthesized inducible enzymes at rates proportional to their concentration of ribosomal $\mathbf{R N A}$. $\mathbf{M g}^{2+}$ limited $A$. aerogenes (as opposed to the $\mathrm{Mg}^{2+}$ depleted organisms used by these workers) did not have a decreased ribosomal content compared with C-limited bacteria grown at the same rate (see also Sykes \& Tempest, 1965), yet were still only able to form $\beta$-galactosidase at a decreased rate (Table 5 ). This suggests differences in the activity of the ribosomes; but other factors (e.g. differences in protein turnover rates) might contribute to the overall result. The absence of significant amounts of polysaccharide from $\mathrm{Mg}^{2+}$-limited bacteria was surprising; presumably the intracellular ' free' $\mathbf{M g}^{2+}$ content was so low that $\mathbf{M g}^{2+}$-requiring enzymes of the glycogen biosynthetic pathway were virtually inactivated. The observation that $\mathrm{Mg}^{2+}$-limited bacteria did not synthesize polysaccharide at a rate comparable to that of C-limited organisms even in the presence of excess free $\mathbf{M g}^{2+}$ indicates quantitative differences in the enzymic constitution of these two types of A. aerogenes. 
The authors are indebted to Dr D. Herbert and Mr R. E. Strange for much useful discussion and criticism of the work. We are grateful to $\mathrm{Mr} \mathrm{T}$. Dunham for his skilled technical assistance.

\section{REFERENCES}

Brock, T. D. (1962). Effects of magnesium ion deficiency on Escherichia coli and possible relation to the mode of action of Novobiocin. J. Bact. 84, 679 .

Brody, S. (1957). Ribonuclease activity and cellular growth. Biochim. biophys. Acta, 24, 502.

Bunton, K. (1956). A study of the conditions and mechanism of the diphenylamine reaction for the colorimetric estimation of deoxyribonucleic acid. Biochem. J. 62, 315.

Callow, D. S. \& Pirt, S. J. (1956). Automatic control of $\mathrm{pH}$ value in cultures of microorganisms. J. gen. Microbiol. 14, 661.

Dixon, M. \& WebB, E. C. (1958). Enzymes. London: Longmans Green and Co. Ltd.

Ecker, R. E. \& Schaechter, M. (1963). Ribosome content and the rate of growth of Salmonella typhimurium. Biochim. biophys. Acta, 76, 275.

Edelman, I. S., Ts'o, P. O.P. \& Vinograd, J. (1960). The binding of magnesium to microsomal nucleoprotein and ribonucleic acid. Biochim. biophys. Acta, 43, 393.

Elsworth, R., Meakin, L. R. P., Pirt, S. J. \& Capelx, C. H. (1956). A two litre scale continuous culture apparatus for microorganisms. J. appl. Bact. 19, 264.

Fales, F. W. (1951). Assimilation and degradation of carbohydrates by yeast cells. J. biol. Chem. 193, 113.

Herbert, D. (1958). Some principles of continuous culture. In Recent Progress in Microbiology. Symp. 7th int. Congr. Microbiol. p. 381. Stockholm: Almquist and Wiksell.

Herbert, D. (1961). The chemical composition of microorganisms as a function of their environment. In Microbial Reaction to Environment. Symp. Soc. gen. Microbiol. 11, 391.

Herbert, D., Elsworth, R. \& Telling, R. C. (1956). The continuous culture of bacteria; a theoretical and experimental study. J. gen. Microbiol. 14, 601.

Hughes, D. E. (1951). A press for disrupting bacteria and other micro-organisms. Brit. J. exp. Path. 32, 97.

Kennell, D. \& Magasanik, B. (1962). The relation of ribosome content to the rate of enzyme synthesis in Aerobacter aerogenes. Biochim. biophys. Acta, 55, 139.

Lucas, J. M., Schuurs, A. H. W. M. \& Srmpson, M. V. (1964). Variation in ribosomal activity and in RNA synthesis during logarithmic growth. Biochemistry, 3, 959.

MCCARTHY, B. J. (1962). Effects of magnesium starvation on the ribosome content of Escherichia coli. Biochim. biophys. Acta, 55, 880.

Mrlitzer, W. E. (1946). Note on the orcinol reagent. Arch. Biochem. 9, 85.

OнTAKA, Y. \& UChIDA, K. (1963). The chemical structure and stability of yeast ribosomes. Biochim. biophys. Acta, 76, 94.

Postgate, J. R., Crumpton, J. E. \& Hunter, J. R. (1961). The measurement of bacterial viabilities by slide culture. J. gen. Microbiol. 24, 15 .

Postgate, J. R. \& Hunter, J.R. (1962). The survival of starved bacteria. J. gen. Microbiol. 29, 233.

Powell, E. O. \& Errington, F. P. (1963). The size of bacteria, as measured with the Dyson image-splitting eyepiece. J. R. microsc. Soc. 82, 39.

Stickiand, L. H. (1951). The determination of small quantities of bacteria by means of the biuret reaction. J. gen. Microbiol. 5, 698.

Sykes, J. \& Trmpest, D. W. (1965). The effect of magnesium and of carbon limitation on the macromolecular organisation and metabolic activity of Pseudomonas sp., Strain C-1B. Biochim. biophys. Acta, (in the press).

Tissières, A. \& Watson, J. D. (1958). Ribonucleoprotein particles from Escherichia coli. Nature, Lond. 182, 778.

WADE, H. E. \& Robinson, H. K. (1963). Absence of ribonuclease from the ribosomes of Pseudomonas fluorescens. Nature, Lond. 200, 661.

WEBB, M. (1949). The influence of magnesium on cell division: 3 . The effect of magnesium on the growth of bacteria in simple chemically defined media. J. gen. Microbiol. 3, 418. 